\title{
PETROGENETIC GRIDS FROM EXPERIMENTAL DATA IN THE SYSTEM $\mathrm{Mn}-\mathrm{Si}-\mathrm{C}-\mathrm{O}-\mathrm{H}$
}

\author{
TJERK PETERS*, JOSE VICENTE VALARELLI**, and MARIA ANGELA \\ F. CANDIA**
}

\begin{abstract}
Experimental data in the system $\mathrm{Mn}-\mathrm{Si}-\mathrm{C}-\mathrm{O}-\mathrm{H}$ are reviewed and equations for equilibrium reactions among common manganese minerals are given. With these equations $T-\log \mathrm{fO}_{2}$ diagrams were constructed, that can be used as petrogenetic grids to evaluate the physical-chemical conditions during the metamorphism of manganese protores. The strong influence of the composition of the fluid phase on the equilibrium temperatures is emphasized. Applications to some natural metamorphic $\mathrm{Mn}$-deposits are shown.
\end{abstract}

RESUMO A reunião de trabalhos experimentais envolvendo equilíbrio entre minerais de manganês e de curvas teóricas de dados termodinâmicos referentes ao sistema $\mathbf{M n}-\mathrm{Si}-\mathrm{C}-\mathrm{O}-\mathrm{H}$, fornece uma visåo do conjunto das paragêneses mineralógicas possíveis de serem encontradas em protominérios e minérios metamórficos naturais. Neste trabalho são fornecidos diagramas isobáricos em função de temperatura e fugacidade de oxigênio de onde se tiram informações sobre o campo de estabilidade dos minerais de manganês mais comuns desse sistema.

Através desses diagramas podem-se interpretar as condições físico-químicas reinantes ou transcorridas durante o metamorfismo, dando-se ênfase à influência da composiçăo da fase fluida $\left(\mathrm{CO}_{2}\right.$, $\mathrm{O}_{2}$ e $\mathrm{H}_{2} \mathrm{O}$, por exemplo) no deslocamento dos equilíbrios.

São dados exemplos de aplicação desses diagramas com base nos dados existentes sobre as paragêneses de dois depósitos de manganês: Morro da Mina (Lafaiete, MG) e Maraú (Bahia).

INTRODUCTION Experimental data at elevated pressures and temperatures for systems containing manganese are rather scarce, although manganese is a common element in most natural rocks. Small amounts of manganese occur in many minerals and petrographic evidence shows, that manganese substitution tends to lower the temperature of formation of common metamorphic minerals:

Besides temperature and pressure the composition of the fluid phase plays an important role in the formation of metamorphic rocks. The influence of oxygen pressure on metamorphic reactions has been experimentally studied by Eugster (1959), French (1966) and others for iron-bearing systems. The importance of the $\mathrm{CO}_{2} / \mathrm{H}_{2} \mathrm{O}$ ratio in the fluid phase on reactions in carbonate-bearing rocks has been shown in experimental studies such as those of Greenwood (1962) and Eugster and Skippen (1967).

Experimental studies of manganese-bearing systems Muan (1959a and b), Mah (1960), Huebner $(1967,1969)$, Huebner and Sato (1970), Peters (1971), Peters, Schwander and Trommsdorff (1973) have permited construction of petrogenetic grids in which temperature, pressure and chemical composition of the solid and fluid phases vary. With the help of such petrogenetic grids it should be possible to estimate the physical chemical conditions of formation of metamorphic manganese deposits. These conditions are of interest for many metamorphic protores. This study will be applied to some examples from Lafaiete and Maraú. This has however a preliminary character, as these and other protores are now being studied by the authors and collaborators.

\footnotetext{
* Mineralogische Institut - Universität Bern

**Instituto de Geociências - Universidade de São Paulo
} 
System $\mathrm{Mn}-\mathrm{O}$ Pyrolusite $\mathrm{MnO}_{2}$, bixbyite $\mathrm{Mn}_{2} \mathrm{O}_{3}$, hausmannite $\mathrm{Mn}_{3} \mathrm{O}_{4}$ and manganosite $\mathrm{Mn}_{1-x} \mathrm{O}$ are the most common manganese oxides found in metamorphic rocks. The reactions occurring between these phases are:

$$
\begin{aligned}
6 \mathrm{Mn}_{1-x} \mathrm{O}+\mathrm{O}_{2} & =2 \mathrm{Mn}_{3} \mathrm{O}_{4} \\
4 \mathrm{Mn}_{3} \mathrm{O}_{4}+\mathrm{O}_{2} & =6 \mathrm{Mn}_{2} \mathrm{O}_{3} \\
2 \mathrm{Mn}_{2} \mathrm{O}_{3}+\mathrm{O}_{2} & =4 \mathrm{MnO}_{2}
\end{aligned}
$$

The equilibrium manganosite-hausmannite-vapour has been studied by several investigators (Hahn and Muan, 1960), Blumenthal and Whitemore (1961), Charette and Flengas (1968), Huebner and Sato (1970). The disagreement between these investigators is partly due to the non stoichiometry of manganosite. The most recent investigation of Huebner and Sato (1970) using an oxygenfugacity cell and a $\mathrm{KCl}$ melt gave reproducible results. From the molar volume data given by Robie and Waldbaum (1968) the pressure correction can be calculated, giving the equation:

$$
\log f_{\mathrm{O}_{2}}=13,55-\frac{26,014}{T}+0,0817 \frac{(P-1)}{T}
$$

The results of Huebner and Sato (1970) using the oxygenfugacity cell in the range $600-900^{\circ} \mathrm{G}$ and the equilibrium curve calculated from Robie and Waldbaum's data (1968) for reaction (2) agree within small limits of error, with those of Hahn and Muan (1960) for high temperatures. Between these and the results from several other investigators Otto (1964), Klingsberg and Roy (1960), Charette and Flengas (1968) there is a large discrepancy. According to Huebner and Sato (1970) the equation for the equilibrium hausmannite-bixbyite-vapour is given by:

$$
\log f_{\mathrm{O}_{2}}=7.44-\frac{9385}{T}+0.0056 \frac{(P-1)}{T}
$$

Since Otto (1965) no new experimental data have been given for the reaction pyrolusite-bixbyite-vapour. Using Robie and Waldbaum's (1968) thermochemical data the calculation of the equilibrium curve is:

$$
\log f_{\mathrm{O}_{2}}=11,01-\frac{8810}{T}+0,0195 \frac{(P-1)}{T}
$$

The total pressure has only a slight influence on the equilibrium curves in the system $\mathrm{Mn}-\mathrm{O}$. The oxygen pressure however is strongly dependant on the temperature. For this reason a petrogenetic grid with temperature and $\log f_{\mathrm{O}_{2}}$ as variables was chosen and the equilibrium curves plotted in this $T$ - $\log f_{\mathrm{O}_{2}}$ diagram for a geologicall reasonable total pressure of 2000 bars.

System $\mathbf{M n - C - O}$. In this system the stability of the manganese carbonate rhodochrosite is of most interest. Depending on the oxygen pressure, rhodochrosite reacts to form manganese oxides with different oxidation states. The reactions are:

$$
\begin{aligned}
\mathrm{MnCO}_{3} & =\mathrm{MnO}+\mathrm{CO}_{2} \\
6 \mathrm{MnCO}_{3}+\mathrm{O}_{2} & =2 \mathrm{Mn}_{3} \mathrm{O}_{4}+6 \mathrm{CO}_{2} \\
4 \mathrm{MnCO}_{3}+\mathrm{O}_{2} & =2 \mathrm{Mn}_{2} \mathrm{O}_{3}+4 \mathrm{CO}_{2} \\
2 \mathrm{MnCO}_{3}+\mathrm{O}_{2} & =2 \mathrm{MnO}_{2}+2 \mathrm{CO}_{2} \\
\mathrm{MnCO}_{3} & =\mathrm{MnO}+\mathrm{C}+\mathrm{O}_{2} \\
\mathrm{CO}_{2} & =\mathrm{C}+\mathrm{O}_{2}
\end{aligned}
$$




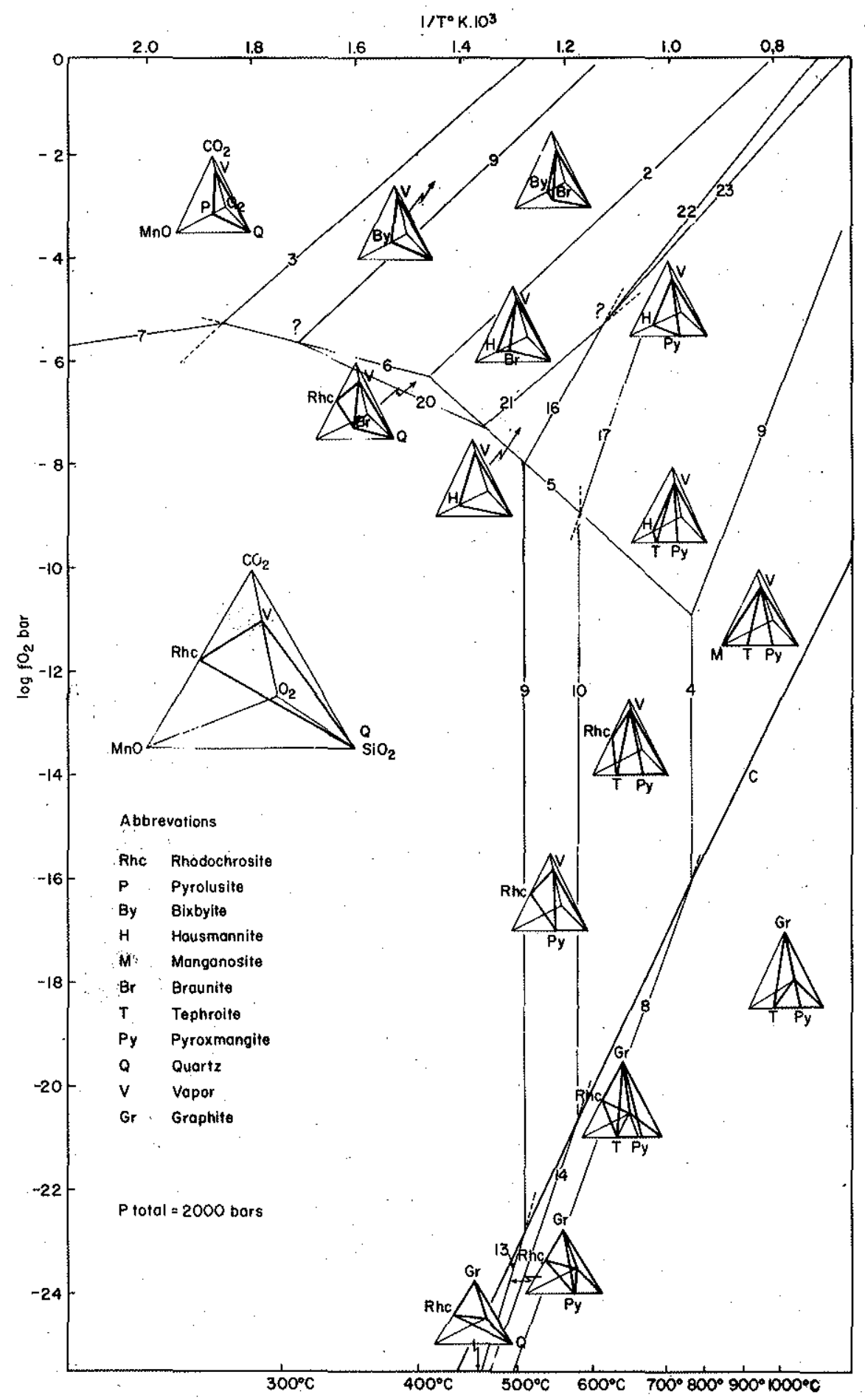

Figure $1-T-\log f \mathrm{O}_{2}$ diagram showing the phase relationships in the system $\mathrm{Mn}-\mathrm{C}-\mathrm{Si}-\mathrm{O}$ at a total pressure of 2.000 bars. Region below graphite buffer curve (C) is condensed with vapour composed only by $\mathrm{O}_{2}$. The numbers refer to equilibrium reactions discussed in the text. Based on experimental data from Muan (1959), Huebner (1967, 1970) and Peters, Schwander and Trommsdorff (1973) 
The decomposition of rhodochrosite into manganosite according to reaction (4) was studied by Goldsmith and Graf (1962) using $\mathrm{CO}_{2}$ as a pressure medium and by Huebner (1969) who used different oxygen buffers. Their results and the curve calculated from the thermochemical data in Robie and Waldbaum (1968) are in excellent agreement. Because of the non stoichiometry of manganosite one would expect the decomposition temperature to be influenced by the oxygen fugacity, but no effect was detected experimentally by Huebner (1969). The equation for the equilibrium curve, based upon the data of Goldsmith and Graf (1967), Huebner (1969) and Robie and Waldbaum (1968) is:

$$
\log K=\log f_{\mathrm{CO}_{2}}=9.036-\frac{5920}{T}+0,0944 \frac{(P-1)}{T}
$$

Assuming no influence by oxygen partial pressure, this curve is represented by a vertical line in the $T-\log f_{\mathrm{O}_{2}}$ diagram (Fig. 1). Reaction (5) according to which rhodochrosite decomposes into hausmannite was studied experimentally by Huebner (1969) using manganosite hausmannite and hausmannite/bixbyite buffers. The equation of the equilibrium curve, based upon his data:

$$
\log K=6 \log f_{\mathrm{CO}_{2}}-\log f_{\mathrm{O}_{2}}=40.91-\frac{9550}{T}+0,486 \frac{(P-1)}{T}
$$

agrees well with the one obtained by addition of the equations for the rhodochrosite-manganosite-vapour (4) equilibrium and the manganosite/hausmannite buffer (1):

$$
\log K_{5}=6 \log K_{4}+\log K_{1}=40.66-\frac{9506}{T}+0,485 \frac{(P-1)}{T}
$$

Calculations based upon Robie and Waldbaum (1968) thermochemical data give a somewhat different equation. The equations given before, however, lie within the limits of uncertainty of the latter. Bixbyite, the form of $\mathrm{Mn}_{2} \mathrm{O}_{3}$ found in several metamorphic manganese deposits, can form from rhodochrosite according to reaction (6). Huebner (1969) studied this reaction experimentally. At a total pressure of 1000 bars he bracketed the equilibrium on the bixbyite/pyrolusite buffer at $230 \pm 35^{\circ} \mathrm{C}$ and at 2000 bars total pressure a temperature of $355^{\circ} \mathrm{C}$ was obtained. Chemographic reasoning shows this last temperature to be too high. (In Fig. 1 the metastable extensions of all three reaction curves would lie in the rhodochrosite field.) Combining the equations for the rhodochrosite-hausmannite-vapour equilibium and the hausmannite-bixbyite buffer:

$$
\begin{aligned}
& 3 \log K_{6}=2 \log K_{5}+\log K_{2} \\
& \log K_{6}=4 \log f_{\mathrm{CO}_{2}}-\log f_{\mathrm{O}_{2}}=24.46-\frac{3238}{T}+0.322 \frac{(P-1)}{T}
\end{aligned}
$$

On the bixbyite/pyrolusite buffer at a total pressure of 1000 bars this equation gives a temperature of $195^{\circ} \mathrm{C}$, that lies within the range of error of the experimentally determined temperature. Calculating the equation from the thermochemical data in Robie and Waldbaum (1968) one can write:

$$
\log K_{6}=4 \log f_{\mathrm{CO}_{2}}-\log f_{\mathrm{O}_{2}}=23.77-\frac{3296}{T}+0,322 \frac{(P-1)}{T}
$$

Temperatures obtained with this equation are about $15^{\circ} \mathrm{C}$ higher than those resulting from the previous equation. 
No experimental data are available for reaction (7), mainly because of the difficulty of attaining equilibrium at the low temperatures involved. A more or less satisfactory equilibrium curve can however be calculated, either from the expressions for the rhodochrosite-bixbyite-vapour equilibrium and the bixbyite/pyrolusite buffer or from thermochemical data. With the first method one obtains the equation:

$$
\log K_{7}=2 \log f_{\mathrm{CO}_{2}}-\log f_{\mathrm{O}_{2}}=6.72+\frac{2786}{T}+0.152 \frac{(P-1)}{T}
$$

Utilizing the equations for the equilibria involving $\mathrm{MnCO}_{3}$, the stability field of rhodochrosite can be limited in the petrogenetic grid (Fig. 1). At very low oxygen fugacities the rhodochrosite-manganosite-vapour equilibrium curve will meet the graphite buffer curve, where $\mathrm{CO}_{2}$ and $\mathrm{CO}$ decompose into graphite and oxygen. Below the graphite buffer curve, of which the data were taken from French and Eugster (1965), the reaction (4) will be replaced by reaction (8) for which the slope can be calculated from equation $(4 a)$ and the equation for the graphite equilibrium $(c)$.

$$
\log K_{8}=\log f_{\mathrm{O}_{2}}=\log K_{4}+\log K_{c}=8.992-\frac{26505}{T}+0.066 \frac{(P-1)}{T}
$$

In the pure $\mathrm{Mn}-\mathrm{C}-\mathrm{O}$ system, where no other gases than $\mathrm{CO}_{2}, \mathrm{CO}$ and $\mathrm{O}_{2}$ are present, the region below the graphite buffer curve is condensed, since besides negligable amounts of $\mathrm{O}_{2}$, there are no other gases present.

System Mn- $\mathbf{M}-\mathbf{C}-\mathbf{S i}-\mathbf{H}$ The most important in this system dealt with in this paper are listed in Table $I$.

\begin{tabular}{|c|c|}
\hline $\begin{aligned} \mathrm{MnCO}_{3}+\mathrm{SiO}_{2} & =\mathrm{MnSiO}_{3}+\mathrm{CO}_{2} \\
\mathrm{MnCO}_{3}+\mathrm{MnSiO}_{3} & =\mathrm{Mn}_{2} \mathrm{SiO}_{4}+\mathrm{CO}_{2} \\
2 \mathrm{MnCO}_{3}+\mathrm{SiO}_{2} & =\mathrm{Mn}_{2} \mathrm{SiO}_{4}+2 \mathrm{CO}_{2} \\
\mathrm{Mn}_{2} \mathrm{SiO}_{4}+\mathrm{SiO}_{2} & =2 \mathrm{MnSiO}_{3} \\
\mathrm{MnCO}_{3}+\mathrm{SiO}_{2} & =\mathrm{MnSiO}_{3}+\mathrm{C}+\mathrm{O}_{2} \\
\mathrm{MnCO}_{3}+\mathrm{MnSiO}_{3} & =\mathrm{Mn}_{2} \mathrm{SiO}_{4}+\mathrm{C}+\mathrm{O}_{2} \\
2 \mathrm{MnCO}_{3}+\mathrm{SiO}_{2} & =\mathrm{Mn}_{2} \mathrm{SiO}_{4}+2 \mathrm{C}+2 \mathrm{O}_{2} \\
2 \mathrm{Mn}_{3} \mathrm{O}_{4}+6 \mathrm{SiO}_{2} & =6 \mathrm{MnSiO}_{3}+\mathrm{O}_{2} \\
2 \mathrm{Mn}_{3} \mathrm{O}_{4}+6 \mathrm{MnSiO}_{3} & =6 \mathrm{Mn}_{2} \mathrm{SiO}_{4}+\mathrm{O}_{2} \\
2 \mathrm{Mn}_{3} \mathrm{O}_{4}+3 \mathrm{SiO}_{2} & =3 \mathrm{Mn}_{2} \mathrm{SiO}_{4}+\mathrm{O}_{2} \\
14 \mathrm{Mn}_{2} \mathrm{O}_{3}+4 \mathrm{SiO}_{2} & =4\left(\mathrm{Mn}_{2} \mathrm{O}_{3}\right)_{3} \mathrm{MnSiO}_{3} \\
14 \mathrm{MnCO}_{3}+2 \mathrm{SiO}_{2}+3 \mathrm{O}_{2} & =2\left(\mathrm{Mn}_{2} \mathrm{O}_{3}\right)_{3} \mathrm{MnSiO}_{3}+14 \mathrm{CO}_{2} \\
3\left(\mathrm{Mn}_{2} \mathrm{O}_{3}\right)_{3} \cdot \mathrm{MnSiO}_{3} & =7 \mathrm{Mn}_{3} \mathrm{O}_{4}+3 \mathrm{SiO}_{2}+\mathrm{O}_{2} \\
2\left(\mathrm{Mn}_{2} \mathrm{O}_{3}\right)_{3} \cdot \mathrm{MnSiO}_{3} & =4 \mathrm{Mn}_{3} \mathrm{O}_{4}+2 \mathrm{MnSiO}_{3}+\mathrm{O}_{2} \\
2\left(\mathrm{Mn}_{2} \mathrm{O}_{3}\right)_{3} \cdot \mathrm{MnSiO}_{3} & =7 \mathrm{MnSiO}_{3}+3 \mathrm{O}_{2} \\
{\mathrm{Mn}(\mathrm{OH})_{2}} & =\mathrm{MnO}_{3}+\mathrm{H}_{2} \mathrm{O} \\
\left.\mathrm{Mn}_{2} \mathrm{OH}\right)_{2}+\mathrm{CO}_{2} & =\mathrm{MnCO}_{3}+\mathrm{H}_{2} \mathrm{O}\end{aligned}$ & $\begin{array}{l}(9) \\
(10) \\
(11) \\
(12) \\
(13) \\
(14) \\
(15) \\
(16) \\
(17) \\
(18) \\
(19) \\
(20) \\
(21) \\
(22) \\
(23) \\
(24) \\
(25)\end{array}$ \\
\hline
\end{tabular}

Table I - Equilibrium reactions in the system $\mathrm{Mn}-\mathrm{O}-\mathrm{C}-\mathrm{Si}-\mathrm{H}$ dealt with in this paper

The stability relationships of the manganese silicates pyroxmangite and tephroite have been studied by Huebner (1967) and Peters (1971) and Peters, Schwander, Trommsdorff (1973). Huebner (1967) used different buffers, varrying the $\mathrm{C} / \mathrm{O} / \mathrm{H}$ ratio and the others made the experiments in $\mathrm{CO}_{2} / \mathrm{H}_{2} \mathrm{O}$ gas mixtures in which the ratio could be varied optionally. The equation for the rhodochrosite-quartz-pyroxmangite-vapour equilibrium, 
reaction (9), using the data from Peters, Schwander and Trommsdorff (1973), can be expressed as:

$$
\log K_{9}=\log f_{\mathrm{CO}_{2}}=18.618-\frac{11961}{T}+0,0983 \frac{(P-1)}{T}
$$

And the equation for the rhodochrosite-pyroxmangite-tephroite-vapour equilibrium, reaction $(10)$ :

$$
\log K_{10}=\log f_{\mathrm{CO}_{2}}=11.870-\frac{7280}{T}+0.0986 \frac{(P-1)}{T}
$$

The pressure correction factor is not accurate, as no reliable new mol volume data for pyroxmangite are yet available. Experiments on these reactions (9) and (10) at a total pressure of 500 bars were carried out at the University of São Paulo. For equilibrium (9) preliminary results give $30^{\circ} \mathrm{C}$ lower temperatures. The temperatures for equilibrium (10) are lowered $70^{\circ} \mathrm{C}$; confirming the equations (9a) and (10a).

Among the phases quartz, pyroxmangite, tephroite and rhodochrosite two other reactions (11) and (12) are possible. These reactions are not independent from reactions (9) and (10). The equilibrium curve for the assemblage rhodochrosite-tephroite-quartz-vapour (11) can be calculated with the expression: $\log K_{11}=\log K_{9}+\log K_{10}$

$$
\log K_{11}=2 \log f_{\mathrm{CO}_{2}}=30.488-\frac{19241}{T}+0,1969 \frac{(P-1)}{T}
$$

Preliminary results on reaction (12) where only the solid phases pyroxmangite, tephroite and quartz participate give an equilibrium temperature of $420^{\circ} \mathrm{C}+10^{\circ} \mathrm{C}$, at a total pressure of 2000 bars. In a $T-X_{\mathrm{CO}_{2}}$ diagram (Fig. 2) the strong influence of the composition $\left(\mathrm{CO}_{2} / \mathrm{H}_{2} \mathrm{O}\right.$ ratio) of the fluid phase on the equilibrium temperature can be nicely demonstrated.

The four reaction curves (9), (10), (11) and (12) will meet in an invariant point at $T=421^{\circ} \mathrm{C}$ and $X_{\mathrm{CO}_{2}}=0,013$. With fluid compositions very rich in $\mathrm{H}_{2} \mathrm{O}$ tephroite can be formed directly from rhodochrosite and quartz and will even be stable at temperatures lower than those for pyroxmangite. This reaction (11) actually occurs in nature, as was demonstrated in the Swiss Alps (Peters, Schwander and Trommsdorff, 1973).

In a $T$ - $\log f_{\mathbf{o}_{2}}$ diagram (Fig. 1) the four equilibria (9), (10), (11) and (12) will plot as vertical lines parallel the $\log f_{\mathrm{O}_{2}}$ - ordinate within the stability field of rhodochrosite. At very low oxygen pressures the equilibrium curves will meet the graphite buffer, where $\mathrm{CO}_{2}$ and $\mathrm{CO}$ decompose and a set of new equilibrium curves are generated, for which the slopes can be calculated from French and Eugster (1962) data for the graphite buffer and the equations $(9 a),(10 a)$ and ( $(1) a)$.

$$
\begin{aligned}
& \log K_{13}=\log K_{9}+\log K_{c}=\log f_{\mathrm{O}_{2}}=18.574-\frac{32548}{T}+0,070 \frac{(P-1)}{T} \\
& \log K_{14}=\log K_{10}+\log K_{c}=\log f_{\mathrm{O}_{2}}=11.826-\frac{27726}{T}+0,071 \frac{(P-1)}{T} \\
& \log K_{15}=\log K_{11}+\log K_{c}=2 \log f_{\mathrm{O}_{2}}=30.400-\frac{60398}{T}+0,133 \frac{(P-1)}{T}
\end{aligned}
$$

At higher oxygen fugacities pyroxmangite and tephroite coexist with hausmannite instead of rhodochrosite. The equations of the equilibria hausmannite-pyroxmangite-quartz-vapour (16), hausmannite-tephroite-pyroxmangite-vapour (17) and hausmannite-tephroite-quartz- 


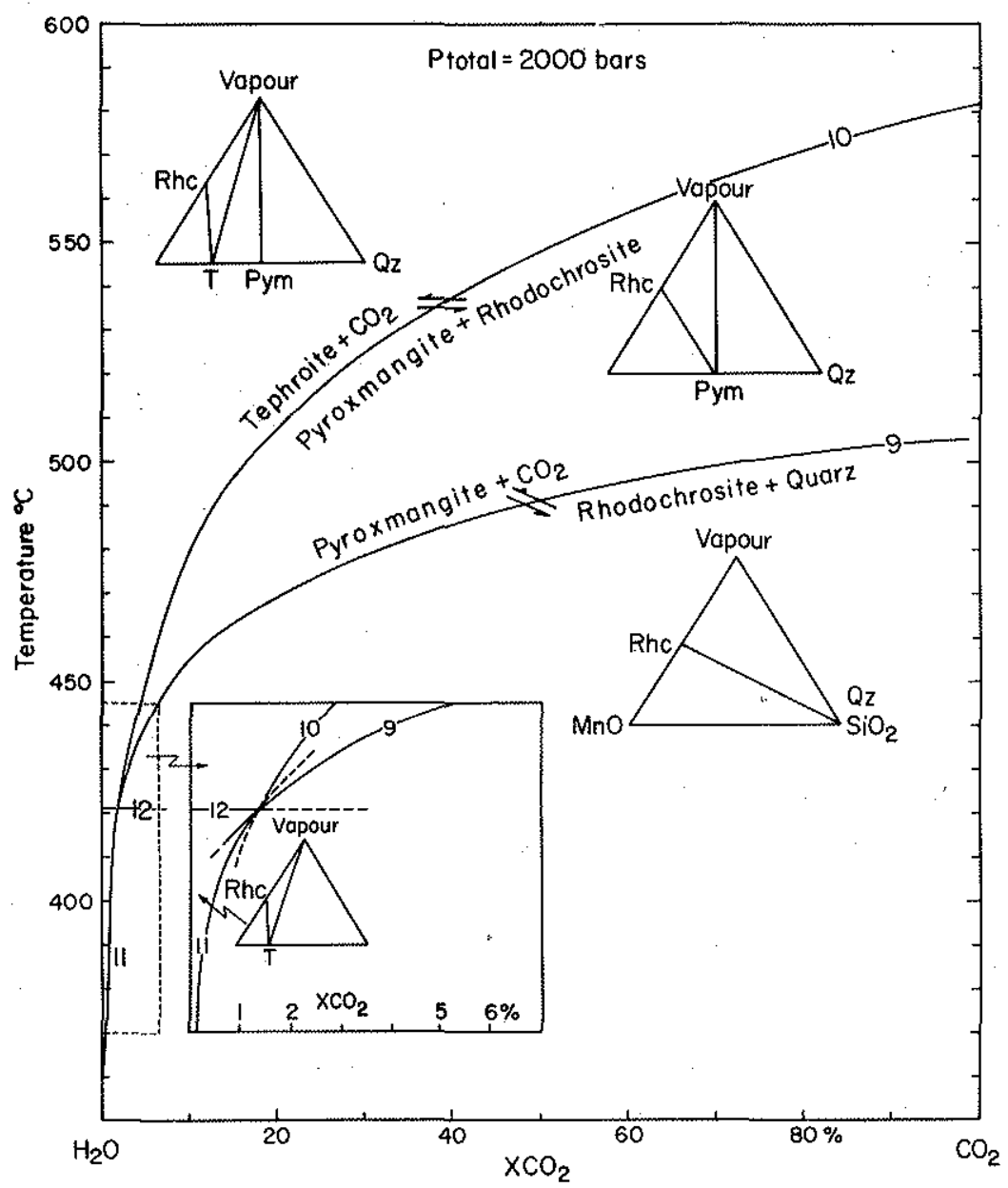

Figure $2-T-\mathrm{X}_{\mathrm{CO}_{2}}$ diagram for reactions among the phases: pyroxmangite, tephroite, rhodochrosite, quartz and vapour. Total pressure of 2.000 bars

-vapour (18) can be calculated from the experimentally determined equilibrium curves:

$$
\begin{aligned}
& \log K_{16}=\log f_{\mathrm{O}_{2}}=6 \log K_{9}-\log K_{5}=71.048-\frac{62266}{T}+0,105 \frac{(P-1)}{T} . \\
& \log K_{17}=\log f_{\mathrm{O}_{2}}=6 \log K_{10}-\log K_{5}=30.56-\frac{34174}{T}+0.1066 \frac{(P-1)}{T} \\
& \log K_{18}=\log f_{\mathrm{O}_{2}}=3 \log K_{11}-\log K_{5}=50.804-\frac{78172}{T}+0.082 \frac{(P-1)}{T}
\end{aligned}
$$

The equilibrium rhodonite-tephroite-hausmannite-vapour was studied experimentally by Muan (1959) at $1 \mathrm{~atm}$ total pressure, using variable oxygen partial pressures. As it is not explicitly mentioned the rhodonite could have been pyroxmangite. The equation for the equilibrium curve obtained $\log p_{\mathrm{O}_{2}}=8.25-\frac{13200}{T}$ differs considerably from the one obtained by combining reactions (11) and (5). This may be due to the large error, that results after the multiplication. The slope for the equilibrium curves (16) and (17) in Fig. 1 is drawn towards Muan's curve. 
Braunite is an important manganese silicate with the general formula $\mathrm{Mn}_{2} \mathrm{O}_{3} \cdot \mathrm{SiO}_{2} \mathrm{ss}$. Natural braunites have a composition close to 10 weight $\% \mathrm{SiO}_{2}$, corresponding to the formula $3 \mathrm{Mn}_{2} \mathrm{O}_{3} \cdot \mathrm{MnSiO}_{3}$. In synthetic braunites the $\mathrm{Mn}_{2} \mathrm{O}_{3} / \mathrm{SiO}_{2}$ - ratio can vary considerably (Muan, 1959). For the equilibrium braunite-bixbyite-quartz-vapour, reaction (19), no experimental data are available. As braunite is more reduced than bixbyite, one may assume that equilibrium curve (19) will lie between the hausmannite/bixbyite and the bixbyite/pyrolusite buffer curves. At the intersection of this equilibrium curve (19) with the rhodochrosite-bixbyite-vapour curve (6) a new equilibrium rhodochrosite-braunite-quartz-vapour (20) is generated. This curve (20) Fig. 1 comprises the part of the rhodochrosite stability field where braunite and rhodochrosite coexist. Where the equilibrium curve (20) meets the rhodochrosite-hausmannite-vapour (5) curve, the curve for the equilibrium braunite-hausmannite-quartz-vapour (21) radiates into the hausmannite field (Fig. 1). For this reaction no experimental data are available, but the reaction curve must pass through an isobaric invariant point where also the equilibrium curves (16), braunite-hausmannite-pyroxmangite-vapour (22) and braunite-quartz-pyroxmangite-vapour (23) intersect. Muan (1959) studied experimentally an analogous reaction braunite-rhodonite-tridymite-vapour, for which he obtained an equilibrium curve, characterized by the expression $\log p_{\mathrm{O}_{2}}=8.56-\frac{12200}{T}$. The equilibrium curve (23) must have a similar slope. In Fig. 1 the equilibrium curves dealing with braunite can only be drawn schematically.

Apart from Klingsberg and Roy (1959) no experimental studies at elevated pressures and temperatures on manganese hydroxydes are available. In their studies, in which the oxygen fugacity was not well controlled only the reaction with pyrochroite-manganosite-water (24) could be reversed. At $3 \mathrm{~kb}$ they obtained an equilibrium temperature of about $430^{\circ} \mathrm{C}$. For this reaction to occur in nature the oxygen-fugacity must be very low, within the $\mathrm{MnO}$ stability field. Also the amount of $\mathrm{CO}_{2}$ in the fluid phase must be small, otherwise rhodochrosite would form according to reaction (25).

System $\mathrm{Mn}-\mathrm{Si}-\mathrm{C}-\mathrm{O}-\mathrm{H}$ with additional compounds like $\mathrm{Ca}, \mathrm{Al}$ and $\mathrm{Fe}$ Preliminary results of experiments in the system $\mathrm{MnO}-\mathrm{CaO}-\mathrm{SiO}_{2}$ carried on in our laboratory in Berne seem to confirm Liebau's. (1959) hypothesis, that pure $\mathrm{MnSiO}_{3}$ crystallizes with a pyroxmangite structure. Additioning only small amounts of $\mathrm{CaO}$ to the system results in the formation of a rhodonite structure. With larger amounts of $\mathrm{CaO}$ bustamite is formed. Recent studies by Akimoto and Syono (1972) on the polymorphism of $\mathrm{MnSiO}_{3}$ at very high pressures seem to indicate that rhodonite is the stable polymorph at low pressures and pyroxmangite at high pressures. In nature however, pyroxmangite is found in metamorphic rocks, that were never exposed to such high pressures as indicated by the study of Akimoto and Syono (1972). Natural rhodonite contains a certain amount of calcium and pure $\mathrm{MnSiO}_{3}$ is only found in nature as pyroxmangite.

Experimental investigations on the stability of spessartite, a very common mineral in metamorphic manganese deposits, have been carried out by $\mathrm{Hsu}$ (1966). He studied the reaction $\mathrm{Mn}$ Chlorite + Quartz $=$ Spessartite in a pure $\mathrm{H}_{2} \mathrm{O}$ atmosphere up to $3 \mathrm{~kb}$. No reversal of this reaction was demonstrated, but an equilibrium curve was drawn through $410^{\circ} \mathrm{C}$ at $P_{\mathrm{H}_{2} \mathrm{O}}=2000$ bars. The spessartite formed from this reaction really is hydrospessartite and only at temperatures abouve $600^{\circ} \mathrm{C}$ water-free spessartite was obtained. In natural rocks occurrences of hydrospessartite are rather scarce. Contrary to the experimental conditions of Hsu (1966) in natural rocks there is generally either an excess of $\mathrm{SiO}_{2}$ 
(quartz-bearing gondites) or the fluid phase is composed of other compounds besides $\mathrm{H}_{2} \mathrm{O}$ (spessartite in carbonatic protore).

The influence of other elements like $\mathrm{Fe}$ and $\mathrm{Mg}$ on manganese-bearing systems have not been investigated for conditions prevailing during metamorphism. By compairing the stability fields of magnesite and siderite with that of rhodochrosite one can predict that magnesium will only have a slight effect as the magnesite decomposition curve is very similar to that of rhodochrosite. Iron however will decrease the stability field of rhodochrosite considerable because siderite (French, 1964) decomposes at lower temperatures and lower oxygen fugacities. The presence of iron in manganese silicates will lower their stability field as the oxydation potential of iron compounds is less than their manganese counterparts.

Petrogenetic Grids Most of the experimentally determined and calculated equilibrium curves, discussed above, are strongly dependant upon temperature and partial pressure of oxygen. The influence of total pressure is much smaller. For this reason the equilibrium curves in the system $\mathrm{Mn}-\mathrm{C}-\mathrm{Si}-\mathrm{O}$ were plotted in a $T-\log f_{\mathrm{O}_{2}}$ diagram for a geologically reasonable total pressure of 2000 bars (Fig. 1). Similar diagrams for other total pressures can be easily calculated from the equations. The isobaric univariant equilibrium curves form a petrogenetic grid. They enclose isobaric divariant fields in which the prevailing phase assemblages are shown. It must be stressed again, that the position of the equilibrium curves dealing with braunite are based upon phase relations occurring in natural rocks and were not experimentally determined. Assuming the fluid phase to be composed exclusively of gases in the system $\mathrm{G}-\mathrm{O}$ it is possible from natural mineral assemblages to derive the temperature and the oxygen pressure of equilibration during metamorphism. Only if an isobaric univariant or even isobaric invariant assemblages are encountered, temperature and $\log f_{\mathrm{O}_{2}}$ can be determined precisely.

During metamorphism of most natural rocks, however, the fluid phase was not only composed of gases in the system $\mathrm{C}-\mathrm{O}_{2}$ but ginerally $\mathrm{H}_{2} \mathrm{O}$ has been present. Besides the presence of hydrous phases, direct evidence can be obtained from the composition of the fluid inclusions in the minerals formed during metamorphism. In reactions like (9) and (10), where only $\mathrm{CO}_{2}$ participates, $\mathrm{H}_{2} \mathrm{O}$ acts as an inert gas. If $\mathrm{H}_{2} \mathrm{O}$ is present in large quantitities the decarbonatization temperatures are considerably decreased ( $\mathrm{Fig}$. 2). In Fig. 3 the manganese buffer reactions are not influenced by the $\mathrm{CO}_{2} / \mathrm{H}_{2} \mathrm{O}$-ratio, as long as no manganese hydroxides are formed. The formation of such hydroxides is ignored in the petrogenetic grids (Fig. 3) as no reliable experimental data are available and occurrences of manganese hydroxides in natural metamorphic rocks are very scarce.

The stability field of rhodochrosite is strongly reduced with decreasing $\dot{X}_{\mathrm{CO}_{2}}$ and moves toward lower temperatures and lower oxigen fugacities (Fig. 3).

With decreasing $X_{\mathrm{CO}_{2}}$ the region, where the assemblage pyroxmangite-rhodochrosite-vapour is stable, deminishes. Below $X_{\mathrm{CO}_{2}}=0.013$, the equilibrium curves (9) with the assemblage rhodochrosite-quartz-pyroxmangite-vapour and (10) with the assemblage rhodochrosite-pyroxmangite-tephroite-vapour are replaced by (11) with the assemblage rhodochrosite-quartz-tephroite-vapour and (12) with the assemblage pyroxmangite-quartz-tephroite. As in the latter reaction (12) only solid phases participate, the equilibrium curve will cross the graphite buffer curve, as well as the rhodochrosite-hausmannite-vapour reaction curve (5). Within the hausmannite field, however, this reaction curve (12) will meet the equilibrium curve (18) with the assemblage hausmannite-quartz-tephroite-vapour, for which the equilibrium constant can be calculated from reactions (11) and (5). The 

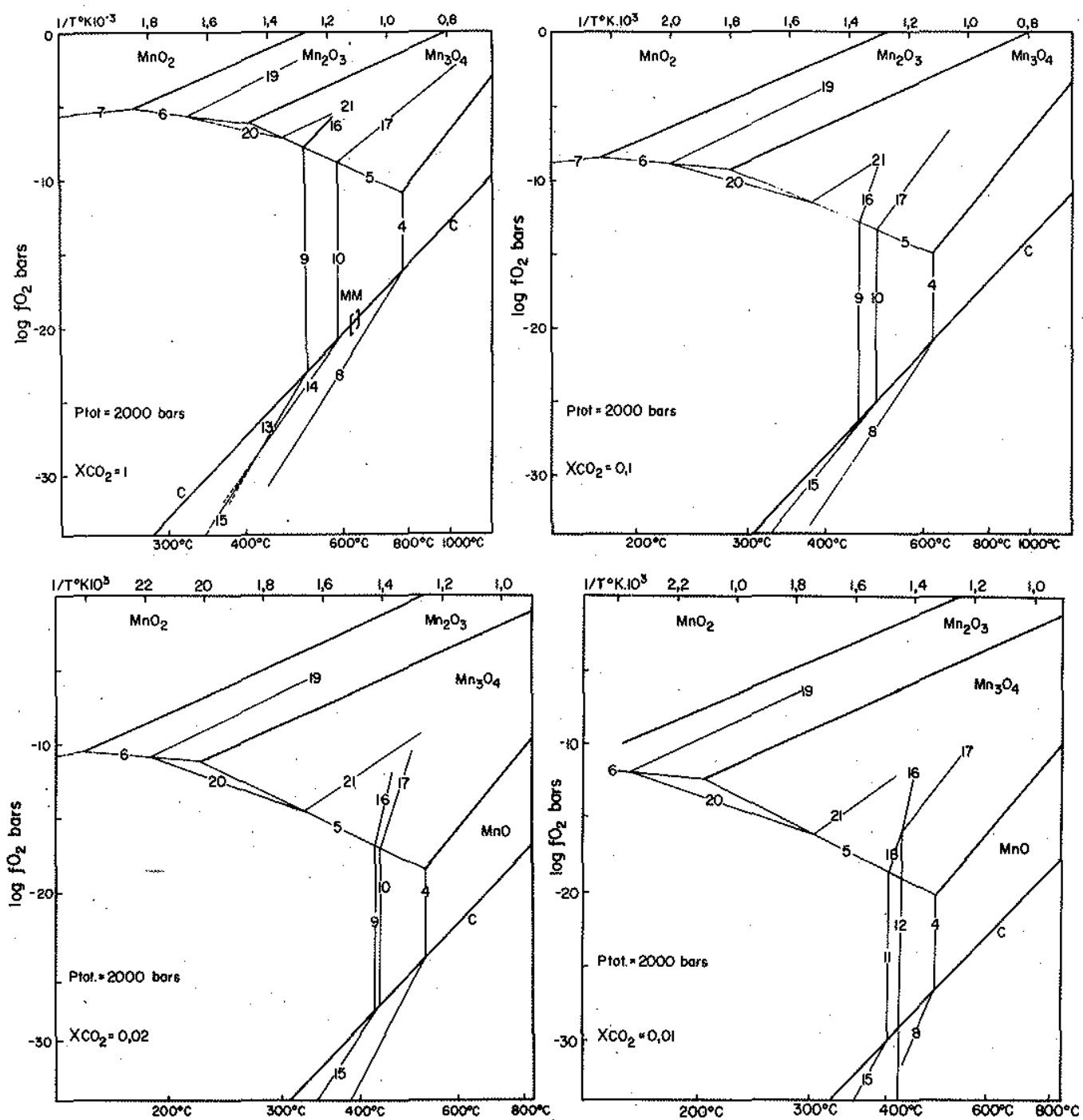

Figure 3 - Sequence of petrogenetic grids $\left(T-\log f \mathrm{O}_{2}\right)$ for different $\mathrm{X}_{\mathrm{CO}_{2}}$. Region where metamorphic manganese deposits of Morro da Mina (MG) and Maraú (BH) equilibrated is marked MM intersection (Fig. 3) is an isobaric invariant point where the equilibrium curves of the reactions (16) and (17) also meet.

Applications The application of the experimentally derived petrogenetic grids to some brazilian metamorphic protores has a preliminary character as the study of the different phase assemblages has only been started. In the Morro da Mina mine, near Lafaiete (MG), known also as the Merid mine (v. Horen, 1959) the following mineral assemblages have been recognized:

rhodochrosite-tephroite

rhodochrosite-tephroite-graphite

rhodochrosite-alabandite-graphite-pyrophanite

pyroxmangite-tephroite-rhodochrosite 
rhodochrosite-tephroite-spessartite-graphite-apatite-pyrophanite spessartite-quartz

The phases occur in these assemblages with typical metamorphic equilibrium texture. The presence of graphite indicates an oxygen fugacity either on or below the graphite buffer (Fig. 3). The presence of the assemblage rhodochrosite-tephroite-hausmannite-graphite described by Horen (1953) could not be confirmed. This can not be an equilibrium assemblage unless extremely high pressures, where the graphite buffer curve crosses the hausmannite/manganosite buffer curve, are assumed. If hausmannite should be present, this would probably be due to oxydation of an other manganese mineral.

The assemblage rhodochrosite-tephroite-pyroxmangite is stable above reaction (10). No manganosite was found indicating that reactions (4) and (8) did not take place. A very $\mathrm{H}_{2} \mathrm{O}$-poor pore fluid may be assumed, as hydrous phases like manganese amphibole have only occasionally been detected in some $\mathrm{SiO}_{2}$-rich veins. In Fig. 3, in a grid with a high $X_{\mathrm{CO}_{2}}$ the assemblage found in Morro da Mina is indicated (MM). Assuming a total pressure of $2 \mathrm{~kb} \log f_{\mathrm{O}_{2}}$ ranges between -19 and -20 and the temperature between 600 and $750^{\circ} \mathrm{C}$. This does not contradict the amphibolite facies of regional metamorphism as inferred from the surrounding rocks (Ebert, 1963, and Fernando Pires, personal communication).

Maraú (Bahia) is an exemple of a metamorphosed manganese protore, where the manganese was originally deposited as oxides. The deposit (Everaldo Gonçalves, personal communication) is found enclosed in granulite facies metamorphic rocks. Besides some spessartite and traces of pyroxmangite hardly any other silicate is found. The main manganese mineral is now cryptomelane in large grains with well developed crytallographic boundaries. This cryptomelane is thought to be pseudomorphous after either hausmannite or manganosite. The latter is more probable as appreciable amounts of graphite are present. During regional metamorphism in granulite facies the ore must have been equilibrated on the graphite buffer curve or below it (Fig. 3). The metamorphism in granulite facies of the surrounding rocks indicates a low partial pressure of $\mathrm{H}_{2} \mathrm{O}$. This deposit has probably been equilibrated under similar oxygen fugacities and slightly higher temperatures than that of the Morro da Mina mine.

The authors intend to extend this study to other metamorphic manganese protores from Brazil such as Serra do Navio (Amapá), Buritirama (Pará) and others. At the same time they are doing experimental work on the system adding elements such as $\mathrm{Al}, \mathrm{Ca}$, and $\mathrm{Fe}$, to explain the mineralogical assemblage of metamorphic manganese deposits that contain spessartite, rhodonite and jacobsite.

Acknowledgements Finantial support from the "Schweizerischer Nationalfonds", the "Conselho Nacional de Pesquisas do Brasil" and the "Fundação de Amparo à Pesquisa do Estado de São Paulo" is greatly acknowledges.

Prof. Dr. B. Evans (Seattle) is thanked for helpful comments.

\section{REFERENCES}

AKIMODO, S. and Y. SYONO - 1972 - High pressure transformation in $\mathrm{MnSiO}_{3}$. Amer. Mineral., 57: 76-84

BLUMENTHAL, R.N. and D. H. WHITMORE - 1961 - Electro chemical measurements of elevated temperature thermodynamic properties of certain iron and manganese oxide mixtures. J. Amer. Ceram. Soc., 44: 508-512.

CHARETTE, G. C. and S. N. FLENGAS - 1968 - Thermodynamic properties of the oxides of $\mathrm{Fe}, \mathrm{Ni}, \mathrm{Pb}, \mathrm{Cu}$ and $\mathrm{Mn}$, by EMF measurements. J. Eletrochem. Soc., 115: 796-804. 
EBERT, H. - 1963 - The manganese bearing Lafaiete formation as a guide horizon in the pre-cambrian of Minas Gerais. An. da Acad. Brasileira de Ciências, 35: 545-559

EUGSTER, H. P. - 1959 - Reduction and oxidation in metamorphism, in: Researches in Geochemistry, ed. by H.P. Abelson, pp. 397-426, John Wiley and Sons, New York

EUGSTER, H. P. and G. B. SKIPPEN - 1969 - Igneons and metamorphic reactions involving gas equilibria, in: Researches in Geochemistry II, ed. by H. P. Abelson, pp. 492-520

FRENCH, B. M. - 1964 - Stability of siderite and progressive metamorphism of iron formation. Ph.D. Dissertation: The Johns Hopkins University, Baltimore, Mariland

FRENCH, B. M. - 1966 - Some Geological implications of equilibriam between graphite and a $\mathrm{C}-\mathrm{H}-\mathrm{O}$ gas phase at high temperatures and pressures: Rev. Geophys, 4: 223-253

FRENCH, B. M. and H. P. EUGSTER - 1965 - Experimental control of oxygen fugacities by graphite-gas equilibriums, Journ. Geophys. Res., 70: 1 529-1 539

GREENWOOD, H. - 1962 - Metamorphic reactions involving two volatile components: Carnegie Institution of Washington, Yearbook, 61: 82-85

HAHN, W. C. and A. MUAN - 1960 - Studies in the system $\mathrm{Mn}$ O: $\mathrm{Mn}_{2} \mathrm{O}_{3} \mathrm{Mn}_{3} \mathrm{O}_{4}$ and $\mathrm{Mn}_{3} \mathrm{O}_{4}-\mathrm{MnO}$ equilibria. Am. J. Sci., 258: 66-78

HOREN, A. V. - 1953 - The manganese mineralization at the Merid Mine, Minas Gerais, Brazil: Ph.D. Thesis, Harvard University.

HUEBNER, J. S. - 1967 - Stability relations of minerals in the system $\mathrm{Mn}-\mathrm{Si}-\mathrm{G}-\mathrm{O}$. Ph.D. Thesis, The Johns Hopkins University, Baltimore, Maryland

HUEBNER, J.S. - 1969 - Stability of rhodochrosite, Am. Mineral., 54: 457-481

HUEBNER, J.S. and SATO, M. - 1970 - The oxygen fugacity - temperature relationships of manganese oxide and nickel oxyde buffers. Am. Mineral., 55: 934-952

HSU, L. - $1966-$ Selected phase relationships in the system $\mathrm{Al}-\mathrm{Mn}-\mathrm{Fe}-\mathrm{Si}-\mathrm{O}-\mathrm{H}$, a model for garnet equilibria: Ph.D. Dissertation, University of California, Los Angeles

KLINGSBERG, C. and ROY, R. - 1960 - Stability and Interconvertibility of phases in the system $\mathrm{Mn}-\mathrm{O}-\mathrm{OH}$. Am. Mineral., 44: 819-838

LIEBAU, F. W. - 1959 - Über die Kristallstruktur des Pyroxmangits. Acta Cryst., 12: 177-181

MAH, A.D. - 1960 - Thermodynamic properties of manganese and its compounds, U.S. Bur. Mines. Rep. Invesh, 5600, $34 \mathrm{pp}$

MUAN, A. - 1959 - Phase equilibria in the system manganese oxide $-\mathrm{SiO}_{2}$ in air. Journ. Sci., 257: $297-315$

MUAN, A. - 1959 - Stability relations among some manganese minerals. Am. Mineral., 44: $946 \div 960$

OTTO, E. M. - 1964 - Equilibrium pressures of oxygen over $\mathrm{Mn}_{2} \mathrm{O}_{3}=\mathrm{Mn}_{3} \mathrm{O}_{4}$ at various temperatures, J. Electrochem. Soc, 111: 88-92

OTTO, E. M. - 1965 - Equilibrium pressure of oxygen over $\mathrm{MnO}_{2}-\mathrm{Mn}_{2} \mathrm{O}_{3}$ at various temperatures. J. Electrochem. Soc., 112: $367-370$

PETERS, TJ. - 1971 - Pyroxmangite: Stability in $\mathrm{H}_{2} \mathrm{O}-\mathrm{CO}_{2}$ Mixtures at a total Pressure of 2000 bars. Contr. Mineral. and Petrol., 32: 267-273

PETERS TJ., SCHWANDER, H. and TROMMSDORFF, V. - 1973 - Assemblages among tephroite, pyroxmangite, rhodochrosite, quartz: Experimental data and occurrences in the rhetic Alps. Contr. Mineral. and Petrol. (in press)

ROBIE, R.A. and WALDBAUM - 1968 - Thermodynamic properties of minerals and related substances at $298.15^{\circ} \mathrm{K}\left(25.0^{\circ} \mathrm{C}\right)$ and one atmosphere (1.013 bars) pressure and at higher temperatures. U.S. Geol. Survey, Bull., 1259

ROY, S. - 1968 - Mineralogy of the different genetic types of manganese deposits. Economic Geology, 63: 760-786

WYLLIE, P. J. - 1962 - The effect of "impure" pure fluids on metamorphic dissociation reations. Mineralog. Mag., 33: 9-25 